\title{
Sustainable Development of Groundwater in East Owienat, Egypt
}

\author{
Heba Abd el-Aziz Abu-Bakr* Manal Abd elMoniem \\ Research Institute for Groundwater. National Water Research Centre, Cairo, Egypt
}

\begin{abstract}
Groundwater is a vital water source in arid and semi-arid regions. In East Owienat area groundwater is an only available water source. This study assessed the characteristics of the hydrogeological system and the baseline condition of the aquifer using field data and numerical modeling. The main objective of this research is to study the impacts of groundwater development on groundwater aquifer sustainability and to select the optimum development scenario, which achieves sustainable development with a minimal effect on aquifer potentiality. Groundwater flow was simulated using the Visual MODFLOW package. The model was calibrated under steady state conditions in January 1985. The model was verified from January 1985 to January 2018 according to observation point's data. The calibrated model then was used for the prediction simulations. Different extraction scenarios were suggested and evaluated to predict the behavior of groundwater aquifer and select the most feasible scenario. The evaluated groundwater extraction scenarios included: current extraction, proposed extraction and seasonally pumping of groundwater scenario. The results indicated that the seasonal operational aquifer scenario is highly recommended for a long-term management plan to achieve groundwater sustainability.
\end{abstract}

Keywords: Groundwater; Sustainable Development; Modflow; East Owienat.

DOI: $10.7176 / \mathrm{CER} / 12-7-06$

Publication date:July $31^{\text {st }} 2020$

\section{Introduction}

The main benefit of groundwater sustainable development is to control unregulated groundwater extraction. Sustainable development was defined as the development which meets the need of the present without compromising the ability of future generations to meet their needs (UN, 1987). The key principles of sustainability in groundwater development are 1) groundwater resource long term saving, 2) groundwater quality protection, and environmental impacts consideration (Gupta \& Onta, 1997). The management of non-renewable groundwater aquifers is focused (Foster et al., 2003).

In recent years groundwater sustainable development has gained more attention all over the world. Several reviews of sustainability have been studied. Several management scenarios were suggested to achieve the sustainability of groundwater in the Dendron dolomitic aquifer of South Africa (Masiyandima et al., 2002). They studied the effect of cropping patterns and irrigation management changes on groundwater levels. The sustainable utilization of Santa Barbra aquifer in California is studied by developing an analytical graphical method considering economic factors, groundwater extraction cost, and groundwater storage (Loaiciga \& Leipink, 2001). A decision support system (DSS) was designed to harmonize groundwater resource exploitation with sustainability in Spain (Manas et al., 2002). The Arab region has a high degree of water stress. He recommended that policy development should be focused on sustainability and integration in Arab region water resources development (Khouri, 2004).

Numerous studies discussed the water flow simulation in East Owienat area. A digital model was developed for East Owienat area to support long term development of irrigated agriculture using the AQUIFEM-1 program (DRTPC \& GPC, 1984). According to thirteen constant pumping tests, the hydraulic conductivity of the aquifer ranged from 5 to $16 \mathrm{~m} / \mathrm{d}$, the transmissivity ranges from 1000 to $3000 \mathrm{~m} 2 / \mathrm{d}$, and the aquifer storativity ranged from 0.05 to 0.15 . Three scenarios were tested and the results indicated that the recommended reclamation area is 189,600 feddans and the related drawdown ranged from $35 \mathrm{~m}$ to $100 \mathrm{~m}$ after 100 years. The groundwater management model was created to study the economic feasibility of groundwater utilization for reclamation of 190,000 feddans by the year 2022 (Ebraheem et al., 2003). The results indicated that the planned extraction rate is not feasible for the coming 100 years. A regional groundwater model was developed, including East Owienat area, the study indicated that groundwater in East Owienat area has a good quality and very high yielding (Lloyd, 1990). The aquifer Transmissivity ranges from 600 to $4900 \mathrm{~m} 2 / \mathrm{d}$, specific yield ranges from 0.08 to 0.15 . The results indicated that drawdown will be $107 \mathrm{~m}$ after 100 years as an outcome of 2000 feddans reclaimed area. Groundwater management options were simulated by 3D GIS based groundwater flow model for East Owienat using the FEflow model (Sefelnasr et al., 2015). Five scenarios were tested to select the most feasible groundwater management scenario with different extraction rates. Hydraulic conductivity ranges from 0.864 to $8.64 \mathrm{~m} / \mathrm{d}$. The results indicated that the drawdown will range from $162 \mathrm{~m}$ to $200 \mathrm{~m}$ after 100 years. To simulate groundwater flow in East Owienat area FEflow model was used to investigate the recharge window length (Masoud et al., 2015). Hydraulic conductivity was assigned in a range from $8.33 \mathrm{~m} / \mathrm{d}$ to $13 \mathrm{~m} / \mathrm{d}$ and the aquifer storativity equal to 0.0345 . The results indicated that with the reclamation of 220,000 feddans, the drawdown will range from $5 \mathrm{~m}$ to $15 \mathrm{~m}$ in the year 2035. 


\section{Materials and Methods}

The overall objective of this work is to clarify the hydrogeological conditions of the study area and to develop groundwater management model to simulate the status quo scenario of the groundwater aquifer in East Owienat area and to propose an efficient extraction scenario to overcome any negative impacts resulting from overexploitation of groundwater in East Owienat area. To satisfy these objectives, the methodology of the research relies mainly on 1) review previous studies on sustainable development, geophysics, geology, hydrogeology and groundwater management; 2) data collecting, including well inventory (both production and observation wells), data of groundwater salinity, pumping tests data, and 3) evaluation of the aquifer system through three-dimensional groundwater flow model using the Visual MODFLOW package.

The identification of the aquifer system is carried out through the development of a flow simulation model. The development of the model involves: identifying all relevant processes and available information, setting up the conceptual and numerical model, calibrating of the model, and using the model as a predictive tool to predict the behavior of the aquifer due to testing scenarios simulation

\subsection{Site description}

East Owienat area is located in the south of Egypt, about $300 \mathrm{~km}$ west of Lake Nasser as shown in Figure 1 It extends between latitudes $27^{\circ} 00^{\prime} 00^{\prime \prime}$ to $29^{\circ} 30^{\prime} 00^{\prime \prime}$ and longitudes $21^{\circ} 30^{\prime} 00^{\prime \prime}$ to $23^{\circ} 30^{\prime} 00^{\prime \prime}$. The study area covers an area of $57100 \mathrm{~km}^{2}$. The area has arid climate conditions, with scarce rainfall and high evaporation rate. The topographic surface slopes from west to the east, where it ranges from $450 \mathrm{~m}$ to $250 \mathrm{~m}$, with some basement outcrops on the ground surface.

\subsection{General geological and hydrogeological settings}

The main groundwater aquifer in the study area is sandstone aquifer. The aquifer consists of sandstone and siltstone interbedded with impermeable shale and clay beds. Geologically, the aquifer ranges from Cambrian to Upper Cretaceous (Thorweihe, 1990). In East Owienat area, coarse to medium-grained Lower Cretaceous fluviatile sandstones are extensive and directly overlying the Precambrian basement.

Hydrogeologically, the aquifer is unconfined in East Oweinat area. Based on the analysis of 34 pumping tests, the aquifer has good storage and medium transmissivity varying from 1000 to $4000 \mathrm{~m}^{2} / \mathrm{d}$. Groundwater quality is generally good (Thorweihe, 1990, Thorweihe 1998). The regional groundwater flows from southwest to northeast direction. Figure 2 shows the hydrogeological cross-sections in East Owienat (RIGW, 1997, RIGW, 2018). It is clear the basement rocks control the lateral and vertical extension of the aquifer within the study area.

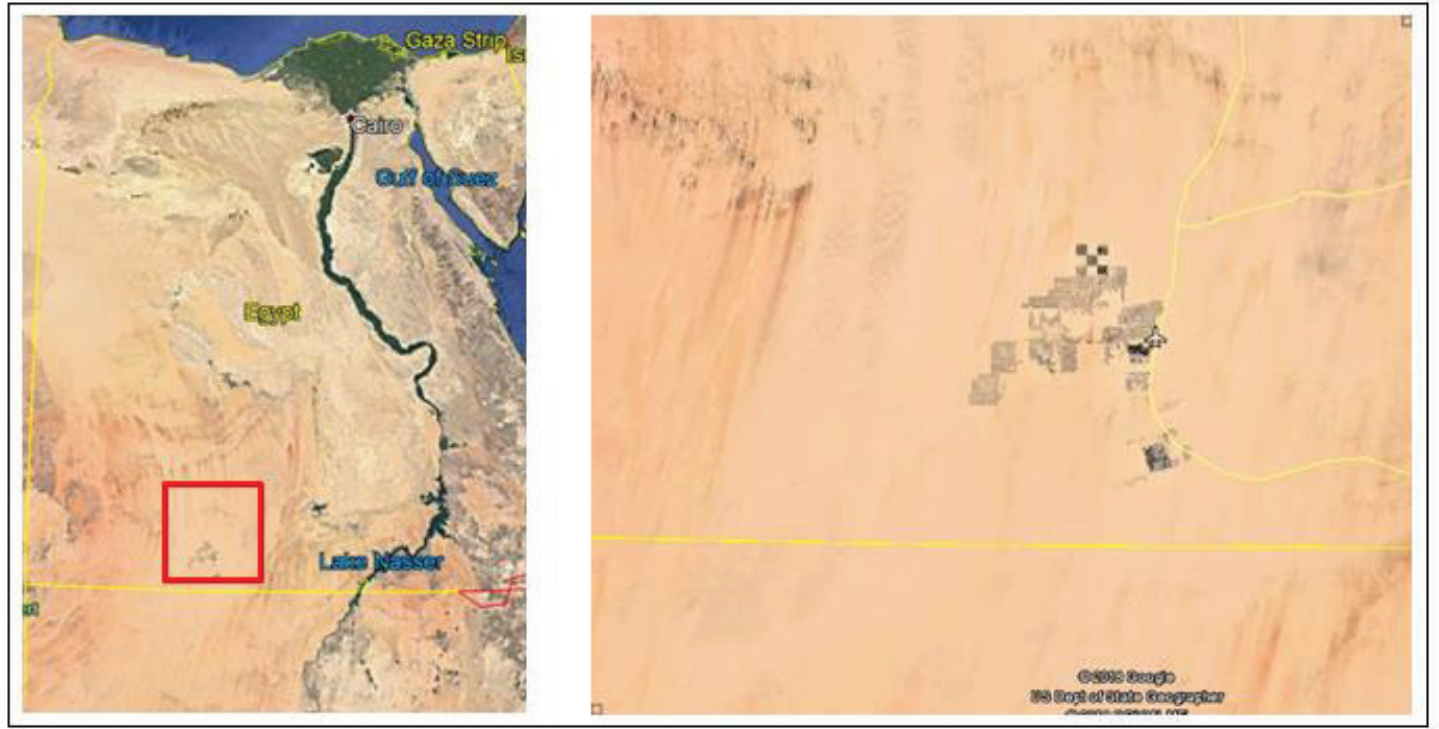

Figure 1. The study area location 


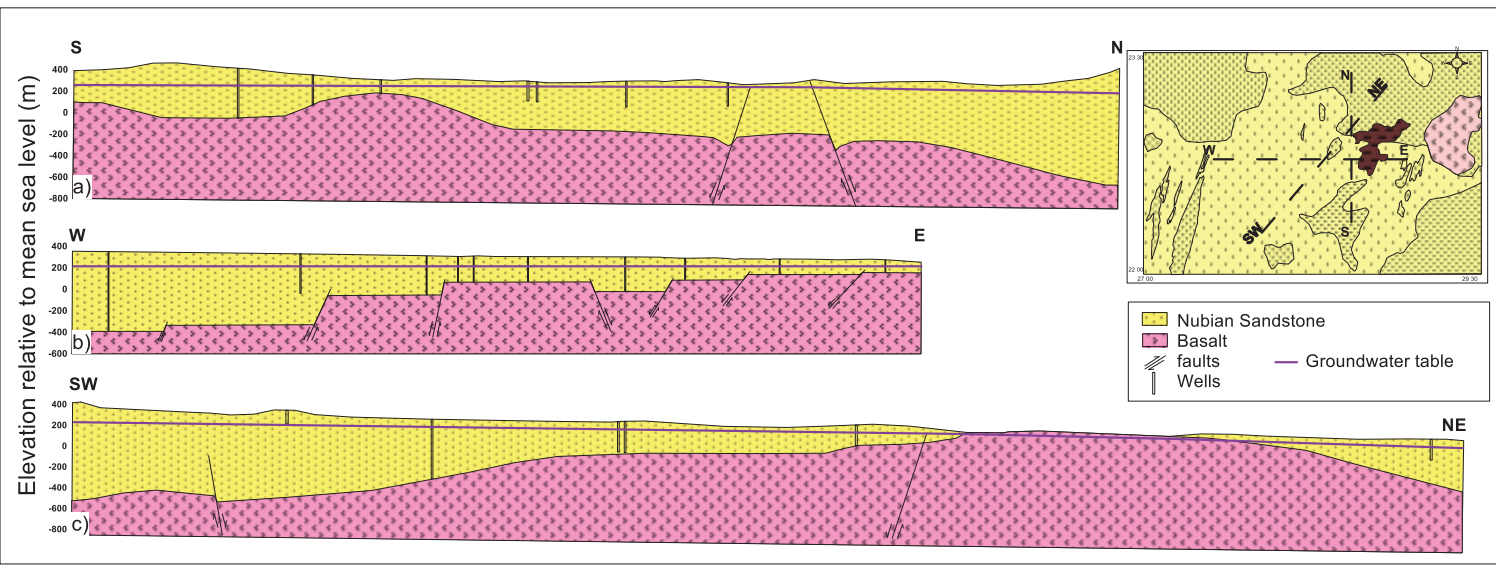

Figure 2. Geology map and hydrogeological cross sections a) south-north cross-section [15], b) west-east cross section [16] and c) southwest-northeast cross-section [15].

\subsection{Groundwater quality}

The groundwater in East Owienat area has good quality. Where the groundwater salinity ranges from 500 to 1000 $\mathrm{mg} / \mathrm{l}$. There are some minor changes in groundwater salinity mainly restricted within areas of extensive groundwater extraction.

\subsection{Groundwater withdrawals}

Groundwater in the study area has been extracted from the aquifer as the only available source of water. Estimated current withdrawals are based on well inventory and surveys done by the Ministry of Water Resources and Irrigation which equals $3.874 \times 106 \mathrm{~m} 3 / \mathrm{d}$ in 2018 . The reclaimed land areas depending on groundwater have rapidly increased with time from 4300 feddan (in the year 1998), to $25000,57000,145000,220000$ feddan in years 2004, 2009, 2014 and 2018 respectively. Figure 3 presents satellite image maps for successive land reclamation development in East Qweinat area from the year 1998 to the year 2018. While Figure 4 shows the related increase in the number of production wells along the same period.

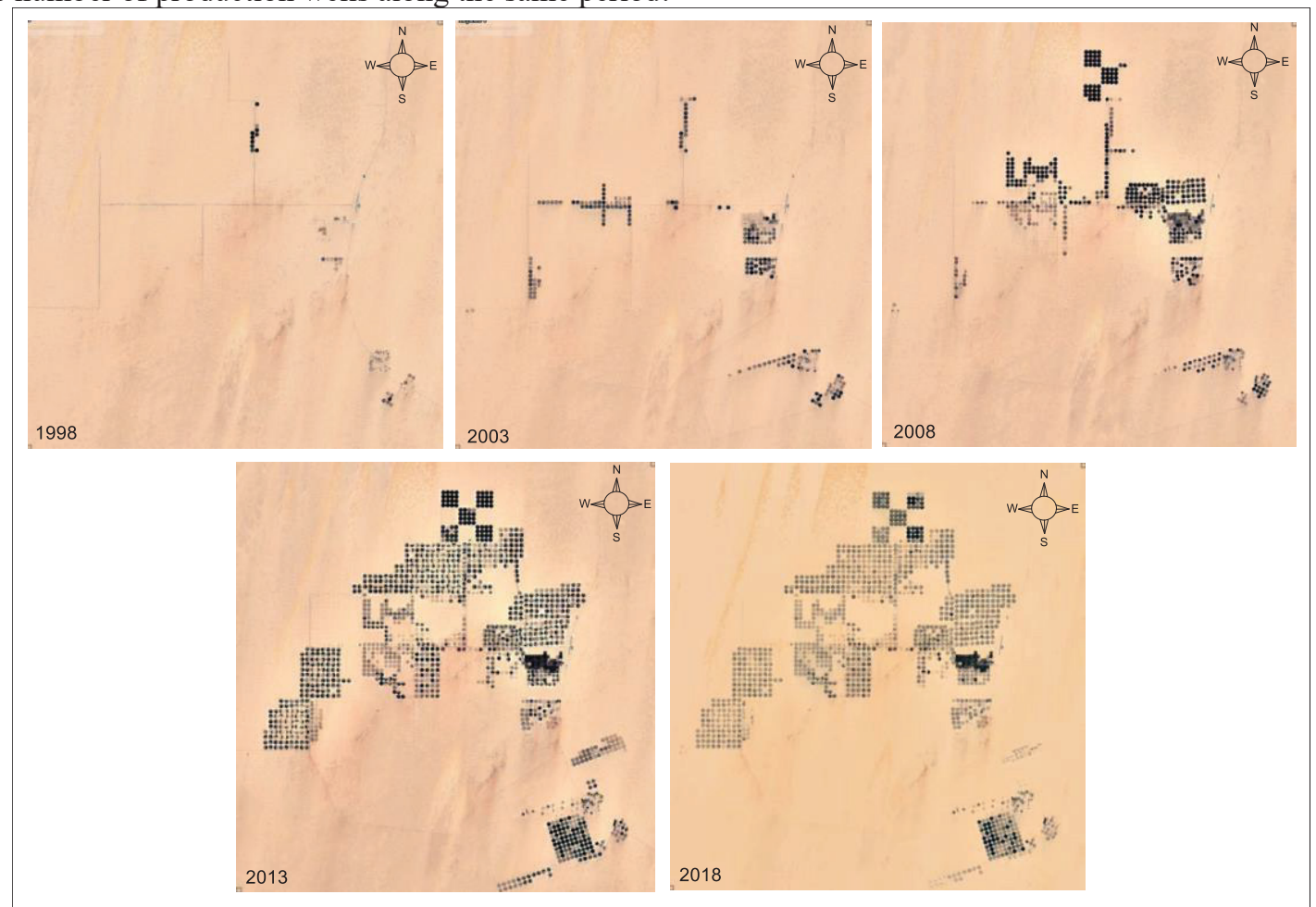

Figure 3. Satellite Image maps showing the rapid increase in land reclamation activities from the year 1998 to the year 2018 in East Owienat area. 


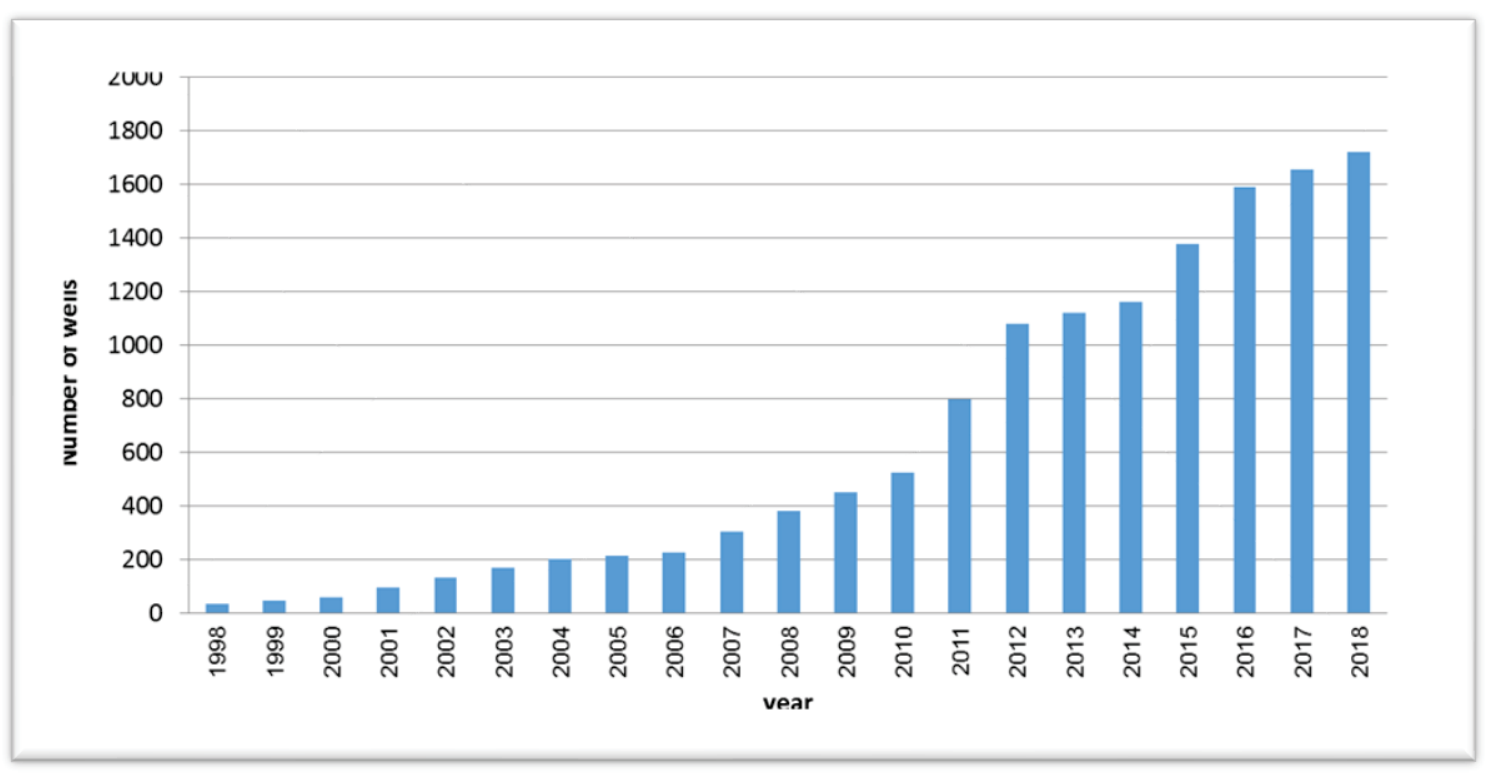

Figure 4. Change in the number of production wells from the year 1988 to the year 2018

\subsection{The conceptual model}

A numerical groundwater flow simulation model was developed to assess the behavior of the aquifer under long term water stresses in East Owienat area. The USGS developed Visual Modflow package which was used to simulate the groundwater flow with the study area. Visual MODFLOW is a computer program that solves the three-dimensional groundwater flow equation using a finite difference method, cells are defined in straight rows and columns and cannot follow the unstraight boundaries. The model is suitable for our study because water has a constant density.

The model is calibrated to head measurements in the year 1985 under steady state conditions. The model is then verified in a transient mode from the year 1986 to the year 2018. To predict the decline in groundwater levels under different extraction scenarios during the next 100 years, the model is used.

A hydrogeological conceptual regional model was developed to simulate the aquifer settings of the study area to evaluate the effects of water management decisions required for flow modeling as shown in Figure 5. The regional model covers an area of about $57100 \mathrm{~km} 2$. The grid size is $750 \mathrm{~m} \times 750 \mathrm{~m}$. A digital elevation model was used to define the topography of the study area. The domain is simulated as one sandstone layer with saturated thickness ranges from 100 to $700 \mathrm{~m}$, underlain by impervious basement rock layer. The geometry of the aquifer is determined from the results of the geophysical electric resistivity surveys, data from drilling wells, and available detailed hydrogeological maps (RIGW, 2108).

January 1985 was chosen as a calibration year to calibrate the model under equilibrium (steady state) conditions because the investigations and the significant changes in groundwater use in East Owienat began in 1985. Water years 1986 to 2018 are chosen to verify the calibrated model under non-equilibrium (transient) conditions. 


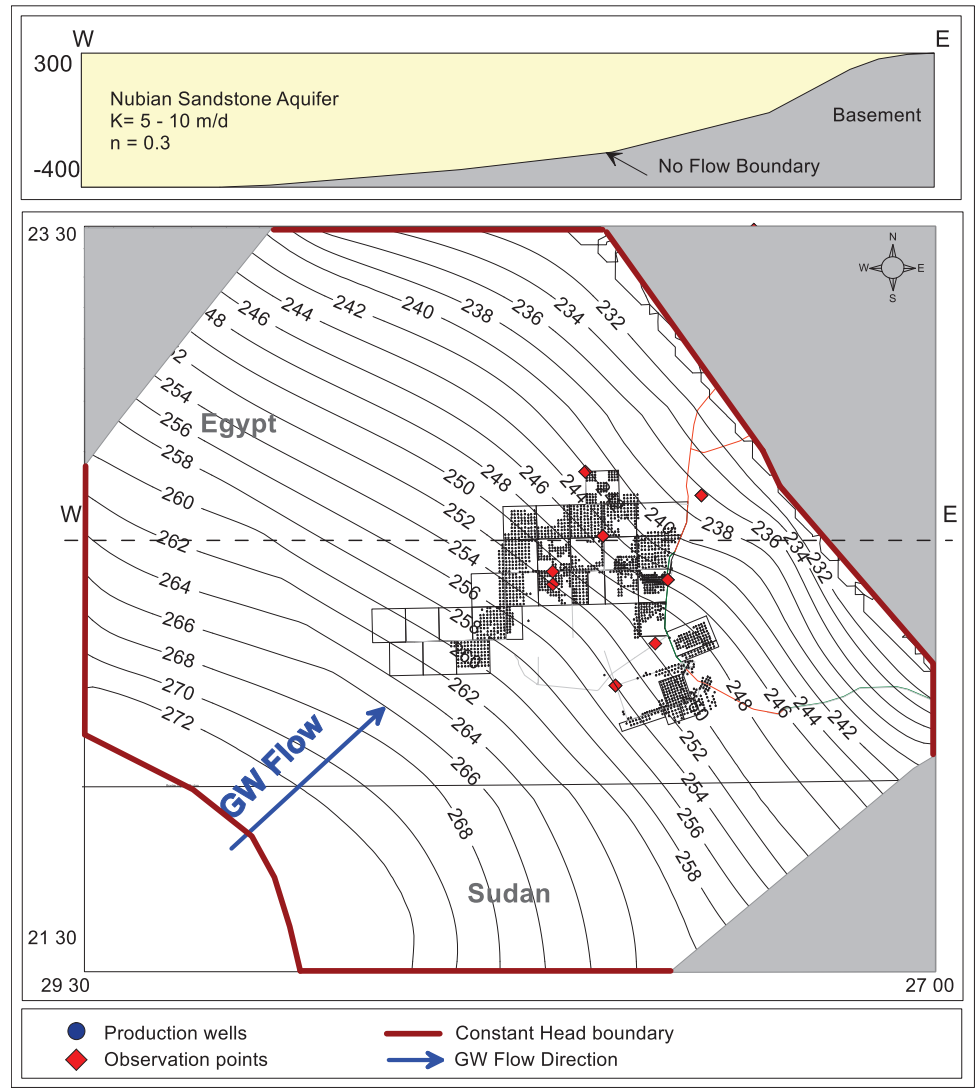

Figure 5. Change in the number of production wells from the year 1988 to the year 2018

\subsection{Numerical simulation}

A numerical model was developed to simulate groundwater flow in East Owienat area. Based on the analysis of pumping test data and the previous studies, the hydraulic conductivity used for the model ranges from 5 to $10 \mathrm{~m} / \mathrm{d}$ and the porosity is 0.3 . Homogeneous conditions are assumed to prevail within each hydrogeological unit. Boundary conditions were assigned in the model. The distance between the boundary conditions and the cultivated area is about $80 \mathrm{~km}$ to ensure that boundary conditions will not be affected by any changes in groundwater levels. The main direction of groundwater flow is from the southwest to the northeast direction. The aquifer system is bounded from the northeast by No flow boundary as the basement rocks are exposed on the ground surface. The west and the southwest boundary were considered as constant head boundary equal to $270 \mathrm{~m}$ relative to mean sea level. The aquifer hydraulic parameters were assigned in the model. The parameters include hydraulic conductivity, storativity, and porosity. Pumping wells were assigned in the model according to the historical data of groundwater extraction. The extraction rate from each well is ranging from 200 to $250 \mathrm{~m} 3 / \mathrm{hr}$. Groundwater withdraws from production wells screened from 250 to $300 \mathrm{~m}$ depth.

\subsection{Calibration}

To achieve the best fit between the observed and calculated head at steady state year, thirteen observation points distributed over the area were used for calibration as shown in Figure 6. Hydraulic conductivity, porosity, and storativity were selected to be calibration parameters. Hydraulic conductivity ranges from 5 to $10 \mathrm{~m} / \mathrm{d}$. Within the study area, the aquifer is considered as an unconfined aquifer with storativity values range from 0.1 to 0.2 . Effective porosity is taken equal to 0.3 . The vertical anisotropy ratio between horizontal and vertical hydraulic conductivity 1:10 was not changed during the calibration or verification stage. Estimated values for hydraulic parameters (hydraulic conductivity, porosity, and storativity) were adjusted by trial and error during model calibration till getting the most accurate results and the smallest difference between measured and calculated heads at steady state year 1985 .

Figure 6 shows groundwater flow levels contour in the year 1985. Figure 7 shows the relationship between measured and calculated heads. Calibration achieved the most accurate result and acceptable RMS value. The calibration indicated that the root mean square error RMS is $0.649 \mathrm{~m}$, the mean absolute error MAE is $0.401 \mathrm{~m}$ and the normalized root mean square error NRMS is 3.4\%. In transient verification, the model was run for a period of 32 years from January 1986 to January 2018. Verification was made in the following years 1997, 2010, 2012, 2015 and, 2018 based on the readings of the observations. The storage coefficient was taken calibration coefficient 
over time. The model was verified by comparing observed heads with calculated heads. Figure 8 shows the observed drawdown in the field versus the calculated drawdown values according to model results in reclamation areas distributed throughout the study area. There are some differences between calculated and measured heads; this dis-matching may be influenced by underestimation and overestimation of groundwater withdrawals and wells operation hours per day.

The sensitivity analysis was conducted on hydraulic conductivity, porosity, storativity, recharge rate from excess irrigation and, boundary conditions. The parameter sensitivity was evaluated using the Root Mean Square Error (RMSE) method. According to the calibration process. A sensitivity analysis of the model indicated that horizontal hydraulic conductivity, storativity, and the boundary conditions are the most sensitive parameters in the model and it is less sensitive to changes in porosity and recharge rate from excess irrigation.

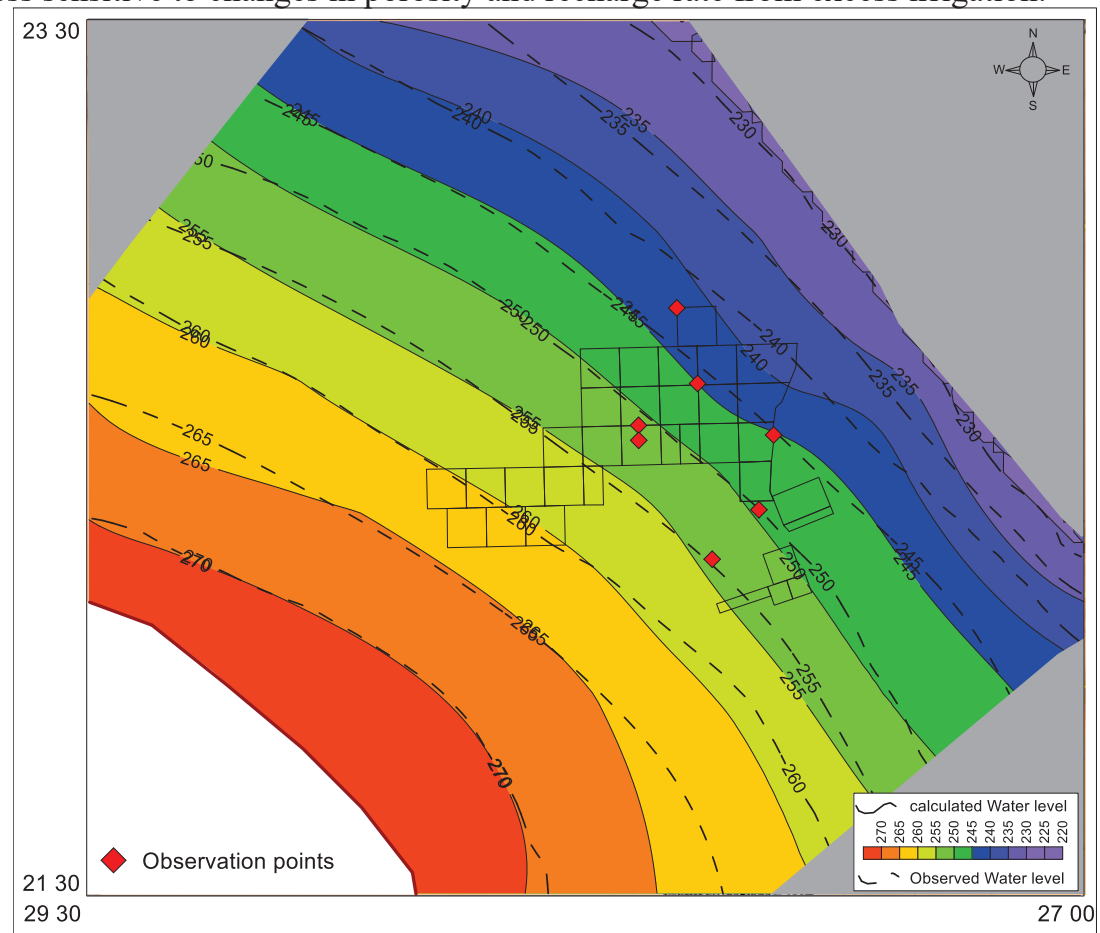

Figure 6. Calculated groundwater levels for the year 1985 (baseline condition)

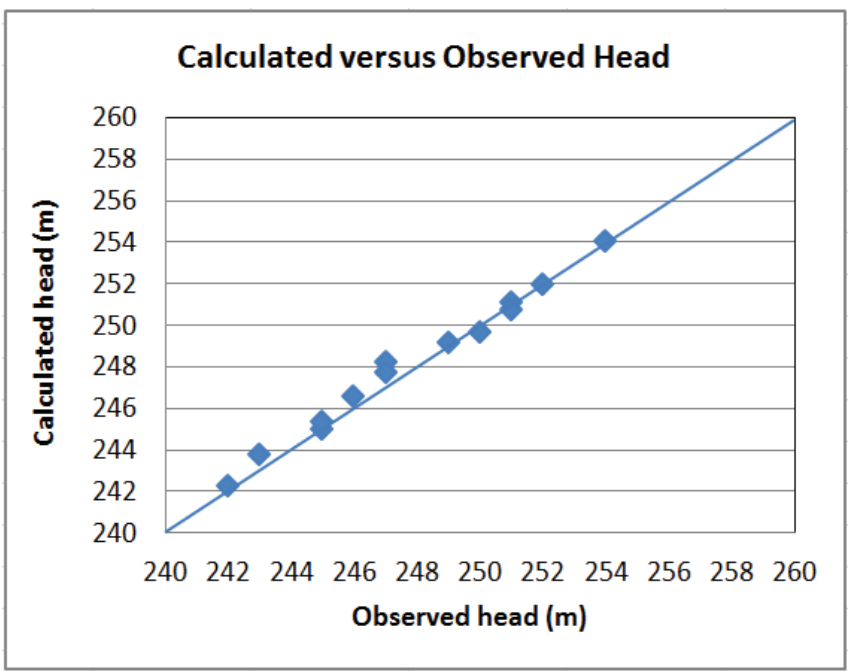

Figure 7. Head calibration curve 

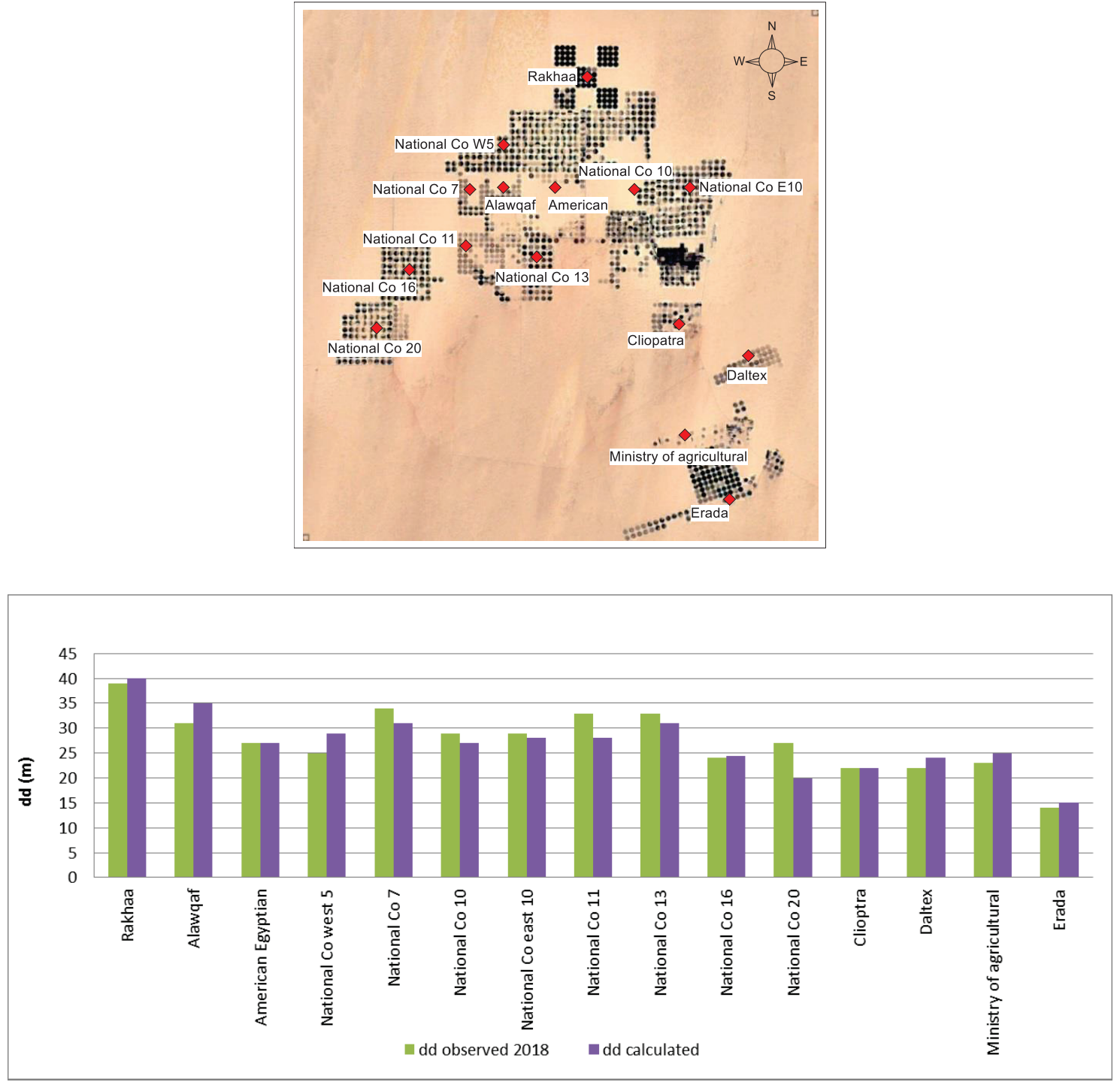

Figure 8. Observed versus calculated drawdown for the year 2018

\section{Results and Discussion}

The criteria implemented for sustainable groundwater development were focused only on the depletion of water levels by time. The model was used to predict the behavior of the aquifer system as a result of different groundwater withdrawal scenarios from the year 2018 to the year 2068. The prediction simulation period was divided into 50 stress periods. Boundary conditions were assumed to keep constant with time. Four scenarios are developed to evaluate the effect of groundwater extraction on the aquifer system in the study area and to assess changes in aquifer behavior. Simulations of future scenarios can provide a useful guide for sustainable management of well operation systems. Drawdown is calculated from steady state January 1985.

\subsection{Evaluation of development scenarios}

Scenario One (Status qua scenario): The model was run to simulate the status quo scenario (i.e., what happens if all conditions remain unchanged until the year 2085). The well extraction rate was $2200 \mathrm{~m}^{3} / \mathrm{d}$ and assuming that the actual pumping rate in the year 2018 is constant for the year 2085 and the total reclaimed area is 220,000 feddan. The results indicate that the maximum drawdown will be $120 \mathrm{~m}$ after 50 years (the year 2035) and will be $270 \mathrm{~m}$ after 100 years (the year 2085) as shown in drawdown contour maps Figure 9. The average lowering in the groundwater level in the study area is estimated by $2.7 \mathrm{~m} /$ year for the whole simulation period. The maximum drawdown values will appear at the center of the pumping area and in the north and east areas where the minimum aquifer thickness exists.

Scenario Two (New reclamation scenario): In this scenario, new reclamation areas were added, where the reclaimed area in Scenario 1 increased by $25 \%$. The extension area is located to the west of the model area. The well abstraction rate was $2200 \mathrm{~m}^{3} / \mathrm{d}$. The drawdown contour maps indicated that the drawdown effects will extend 
to the west of the study area after 50 and 100 years as shown in Figure 10. The results indicate that the maximum drawdown in the study area will be $120 \mathrm{~m}$ after 50 years (the year 2035) and $270 \mathrm{~m}$ after 100 years (the year 2085).

Scenario Three (change well abstraction rate): This scenario is applied to simulate the response of the aquifer to the withdrawal regime. Where no of wells is the same as scenario2 with changing in well abstraction rate to be $1850 \mathrm{~m}^{3} / \mathrm{d}$ per well. The results indicate that the maximum drawdown in the study area will be $100 \mathrm{~m}$ after 50 years (the year 2035) and will be $230 \mathrm{~m}$ after 100 years (the year 2085) as shown in Figure 11.

Scenario Four: (Seasonal Operation scenario): This scenario is applied to test the impact of the operational regime. Where the same extraction rate of scenario2 is used and the well abstraction rate is $2200 \mathrm{~m}^{3} / \mathrm{d} \mathrm{but} \mathrm{the}$ operation of wells is seasonal. The wells are in operation for 6 months and stop or decrease the extraction for another 6 months.

In East Owienat area the common cropping pattern is wheat, maize, and cotton which have high water requirements and also have high economic returns. In this scenario, the irrigation periods were divided into two periods by changing the cropping pattern. In the first season wheat, maize and cotton can be planted as followed in the current state and in the other season of irrigation, the cropping pattern can be changed to crops with few water requirements and high economic returns such as aromatic plants.

The results show that the maximum drawdown will decrease by about half. As it will be $60 \mathrm{~m}$ after 50 years (the year 2035) and will be $120 \mathrm{~m}$ after 100 years (the year 2085) in the study area as shown in drawdown contour maps in Figure 12. Seasonal changes in drawdown are linked to seasonal changes in pumping rates. The results indicate that the seasonal cropping pattern and seasonal extraction to allow the aquifer to recover, which reduces the drawdown in groundwater levels about half of the drawdown values.

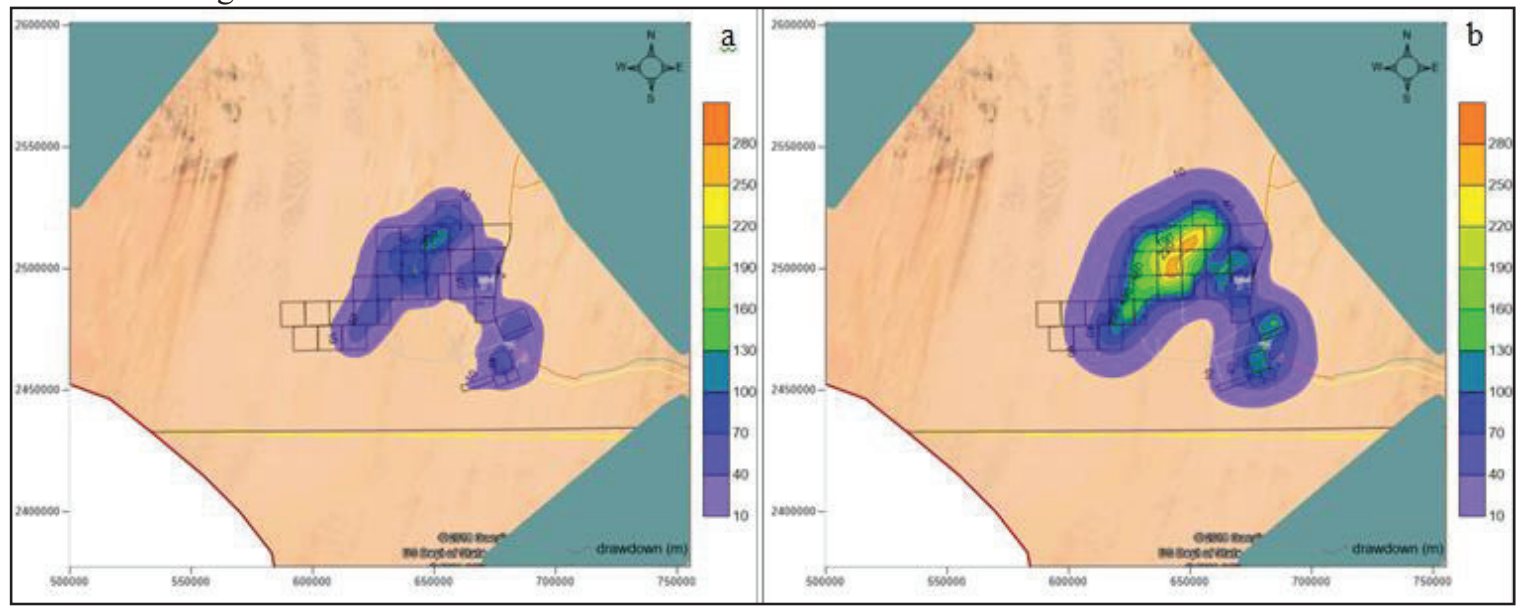

Figure 9. Drawdown Contour Maps in Years 2035 \& 2085 (First Scenario)

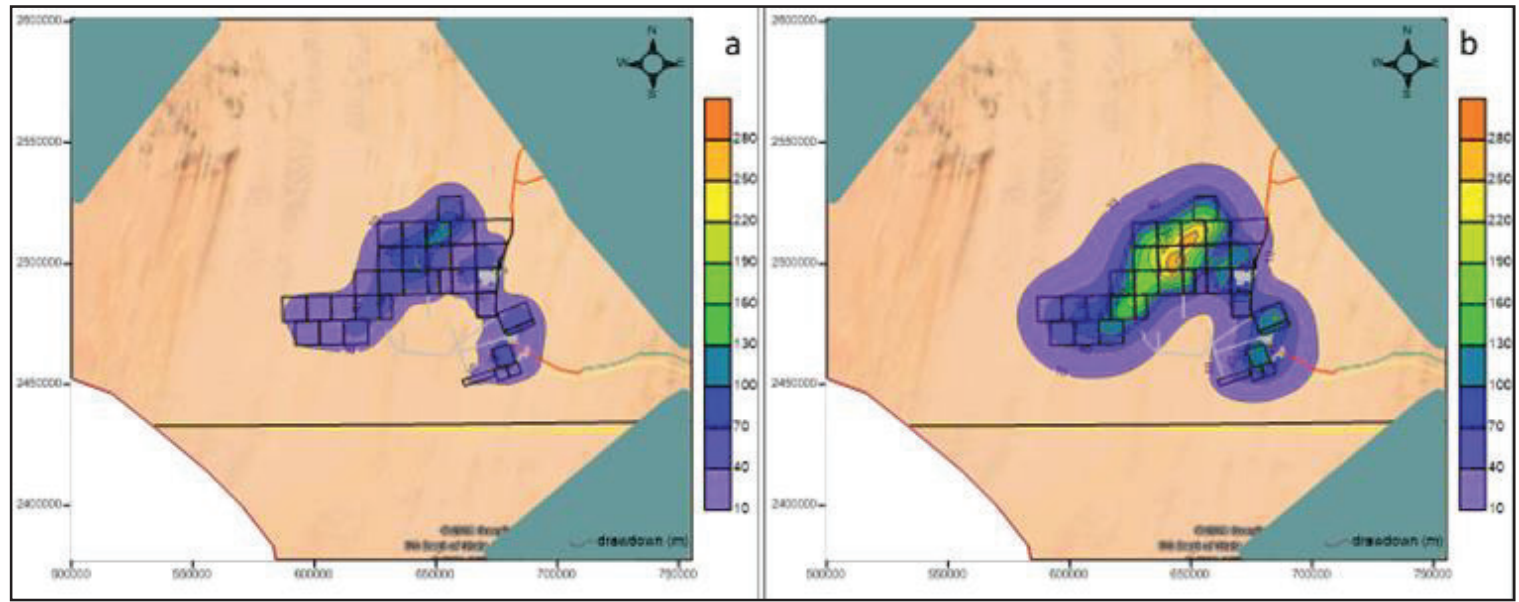

Figure 10. Drawdown Contour Maps in Years 2035 \& 2085 (Second Scenario) 


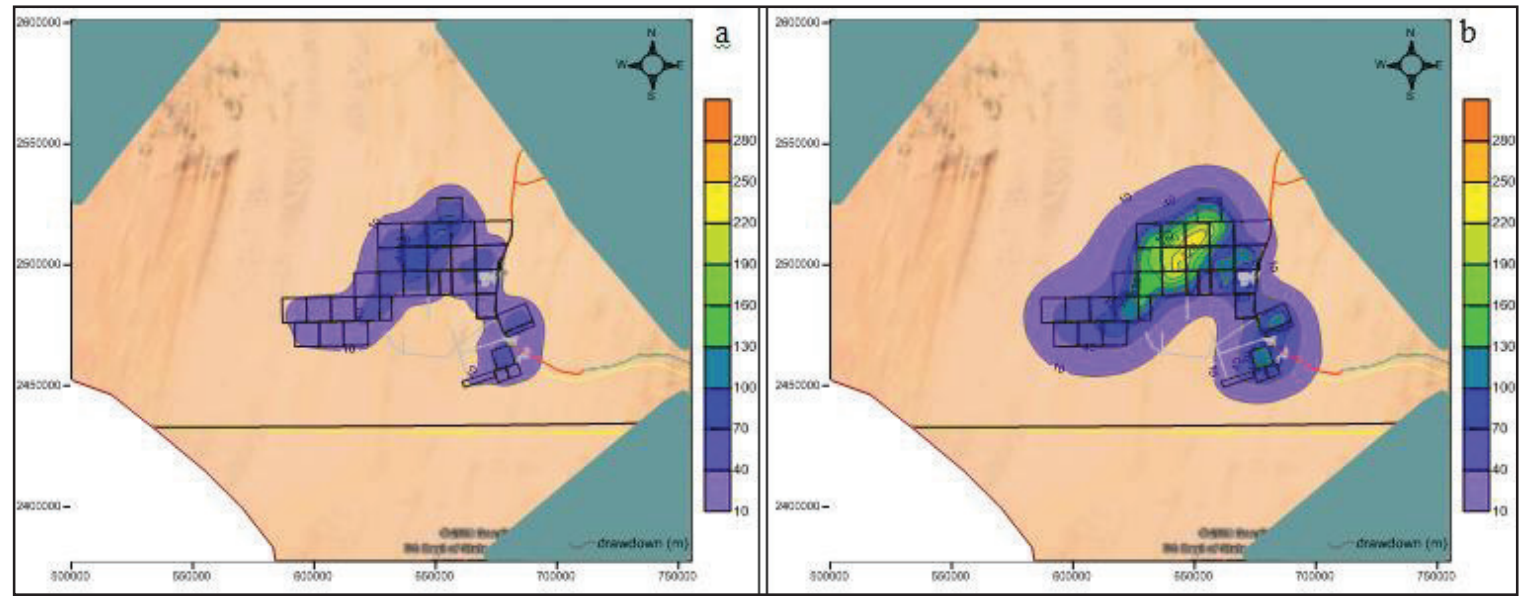

Figure 11. Drawdown Contour Maps in Years 2035 \& 2085 (Third Scenario)

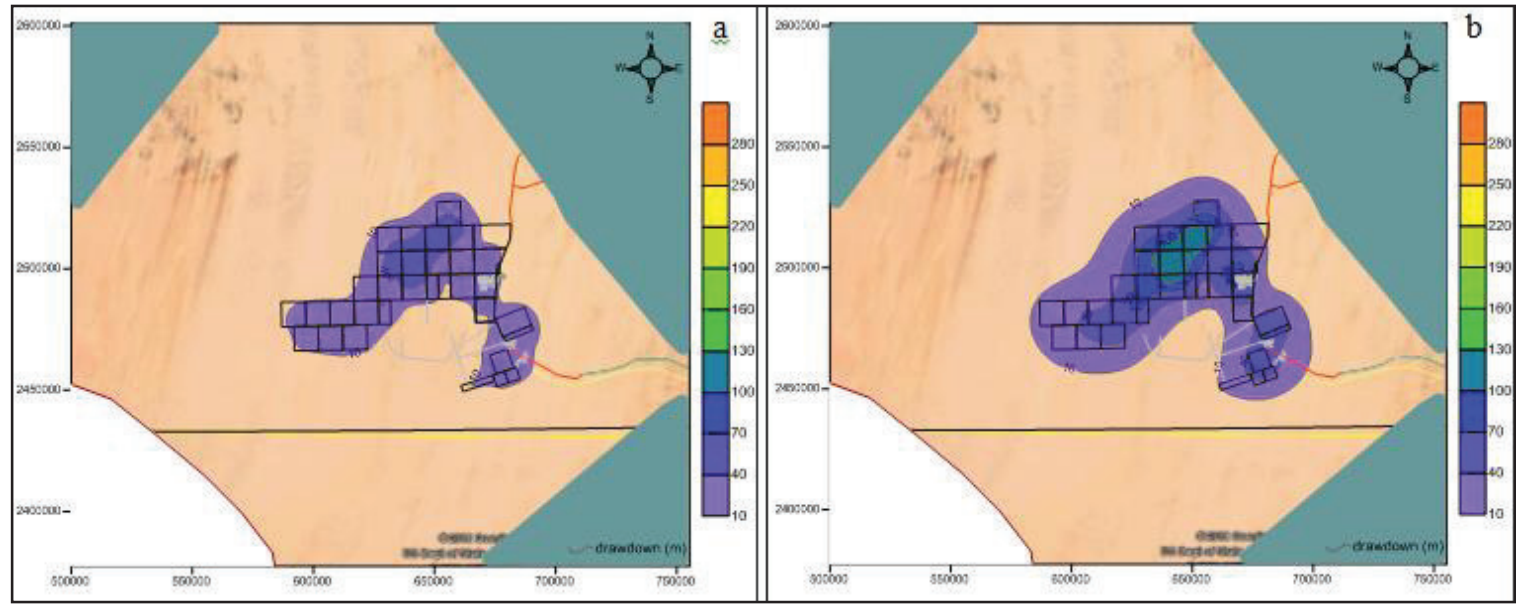

Figure 12. Drawdown Contour Maps in Years 2035 \& 2085 (Fourth Scenario)

\subsection{Prediction results}

Four groundwater development scenarios were proposed and evaluated to predict drawdown values with time as a result of different extraction rates and different operating systems. The initial regional direction of groundwater flow is from southwest to northeast. As a result of continuous groundwater pumping, local radial groundwater flow direction exists, where the groundwater moves towards the center of the development areas. Drawdown at three observation points' obs1, obs2, and obs3 were calculated as shown in Figure 14. The curves show that the maximum drawdown has appeared in obs 2 the center of the development area.

The prediction results of future scenarios indicated that an effective management plan to enhance groundwater utilization and to minimize the negative impacts on the aquifer system could be achieved by applying seasonally operation scenario and changing the cropping pattern. Applying such a scenario will give the opportunity for the aquifer to recover during the period of decreasing or stop pumping.

For the first three scenarios, groundwater extraction will lead to groundwater drawdown in excess of $150 \mathrm{~m}$ in East Owienat. These large groundwater level declines will cause a reduction in the saturated thickness of the aquifer exceeding $50 \%$ of the saturated thickness. This will lead to increase in pumping lifts and declining in well yield. The fourth scenario will decrease groundwater levels about $100 \mathrm{~m}$; this will cause about $25 \%$ of the saturated thickness and it will be more sustainable to conserve the aquifer in East Owienat. 

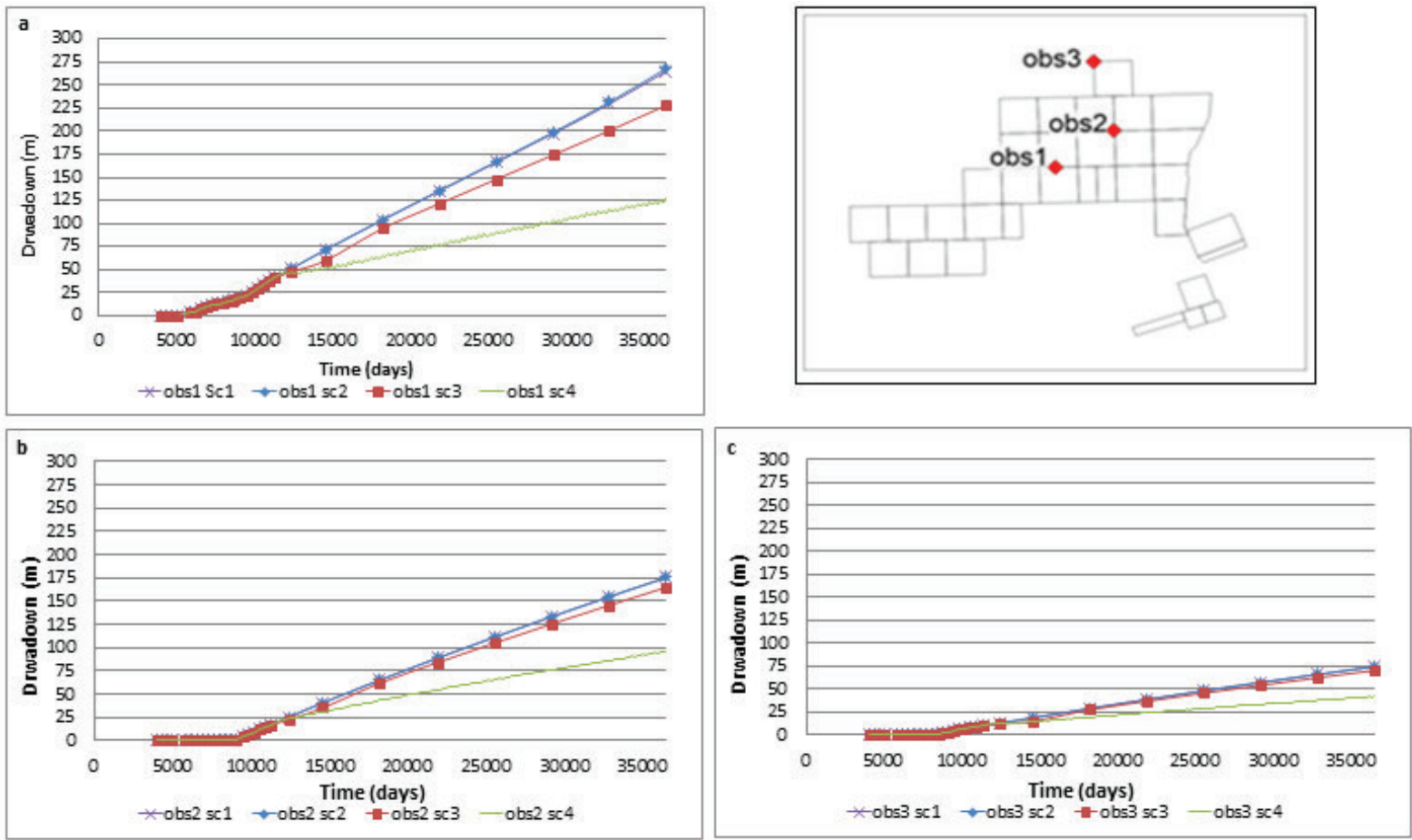

Figure 13. Drawdown values at observation points with time for all scenarios a) obs1, b) obs2, c) obs3

\section{Conclusion}

This paper presents the different proposed scenarios to achieve sustainability of groundwater development in East Owienat area. The conclusions from the present study are mainly based on the field data analysis which was used to detect the prevailing hydrogeological environment. The concept of the study proposed a long term management plan to achieve sustainability. A conceptual flow model (MODFLOW) was implemented to simulate and calibrate the groundwater flow in East Owienat area based on the groundwater levels during the period between January 1985 (before starting the reclamation activities) and January 2018. Four scenarios were evaluated based on the final results of the verification period (1985-2018) to predict the impact of the different groundwater withdrawals on the aquifer behavior with time. The output of the four future scenarios (maps and graphs) was a helpful tool to predict the future hydrogeological situation of the aquifer system and to select the reliable, applicable and secure scenario as outlined for long term sustainable development. Before starting the groundwater development in East Owienat, the initial groundwater regional flow was flowing from southwest to northeast direction. While by continuous groundwater development, the flow was changed as radial flow towards the center of the well field in the development area, as a result of the excessive groundwater extraction. Application of numerical modeling has been proven to be efficient and accurate. It proved that the seasonal operational aquifer scenario is highly recommended for a long term management plan to achieve groundwater sustainability. More aquifer operation scenarios should be trying to assess the water duty, crop pattern, and taking into consideration the salinity in terms of enhancing the groundwater potential. Continuous groundwater monitoring for groundwater level, salinity, and extraction rates is a very important tool in groundwater management.

\section{References}

Abd el Karim, M. H., (2009) "Role of Groundwater Evaporation Losses on the Available Water Resources, Western Desert of Egypt”, Journal of Engineering and Applied Science, 56 (1), 1-19.

Abrishamchi, A., Khakbazan, F., and Taghavim A., (2020) "Planning for Groundwater Sustainable Use: A Case Study in Nishapur Plain, Iran", Agricultural Water Management, 229, 1-15.

DRTPC \& GPC., (1984) “Groundwater Resource Evaluation of East Owienat Area South Western Desert Report”, Cairo University.

Ebraheem, A. M., Garamoon, H. K., Riad, S., Wycisk, P. and Seif El Nasr, A. M., (2003) "Numerical Modelling of Groundwater Resource Management Options in the East Oweinat Area, South West, Egypt", Environmental Geology, 4, 433-447.

Foster, S., Nanni, M., Kemper, K., Garduno, H. \& Tuinhof, A., (2003) "Utilization of Non-Renewable Groundwater a Socially-Sustainable Approach to Resource Management Groundwater Management. Sustainable Groundwater management: concepts and tools", GW-mate (Groundwater Management Advisory 
Team) Global Water Partnership Associate Program Briefing Note No.11, World Bank.

Gupta, A. D. \& Onta, P. R., (1997) "Sustainable Groundwater Resources Development”, Hydrogeological Sciences Journal, 42 (4), 565-582.

Harbaugh, A.W., MODFLOW, (2005) the U.S. Geological Survey Modular Groundwater Model the Groundwater Flow Process: U.S. Geological Survey Techniques and Methods.

Khouri, J., (2004) "Sustainable Development and Management of Water Resources in the Arab Region", Journal of Hydrology, USA, 117 (4), 199-220.

Koosha, K., and Emaminejad, N., (2019) "Sustainable Development in Cities: Studying the Relationship between Groundwater Level and Urbanization using Remote Sensing Data", Groundwater for Sustainable Development, 9, 1-12.

Loaiciga, H. A. and Leipink, R. B., (2001) "Theory of Sustainable Groundwater Management: an Urban Case Study", Urban Water Journal, 3 (3), 217-228.

Lisa, G., Paula U., Karen G., and Vladimir S., (2018) "Groundwater and Sustainable Development Goals: Analysis of Interlinkages", UNU-INWEH Report Series Issue 04, UNU-INWEH Report Series, Issue 04. United Nations University Institute for Water, Environment and Health, Hamilton, Canada.

Lloyd, J.W., (1990) “Groundwater Resources Development in the Eastern Sahara. Journal of Hydrology”, Elsevier Science Publishers, Amsterdam, 119, 71-87.

Manas, F. M., Ramos, A. B., Cortes, C. F., Gonzalez, D. F. and Corcoles, H. L., (2002) "Improvement of Irrigation Management towards the Sustainable Use of Groundwater in Castilla-La Mancha, Spain", Agricultural Water Management Journal, 40, 195-205.

Masiyandima, M., Stoep, I. V., Mwanasawani, T. \& Pupaiena, S. C., (2002) “Groundwater Management Strategies and their Implications on Irrigated Agriculture: the Case of Dendron Aquifer in Northern Province, South Africa", Physics and Chemistry of the Earth, 27 (11), 935-940.

Masoud, M.H., Schneider, M. and El Osta, M.M., (2015) "Recharge Flux to the Nubian Sandstone Aquifer and its Impacts on the Present Development in Southwest Egypt", Journal of Arid Environments, 122 (1), 46-58.

Raghavendra, S., and Chandra, P., (2015) "Sustainable Development and Management of Groundwater Resources in Mining Affected Areas: A Review”, Procedia Earth and Planetary Science, 11, 598-604.

RIGW, (1997) "Hydrogeological Mapping of Egypt", Bir Misaha, scale 1:500,000. 1st edition; published by Academy of Scientific Research and Technology.

RIGW, (2018) "Digitizing and Updating of Hydrogeological Maps for Selected Development Areas", published by Academy of Scientific Research and Technology.

Sefelnasr, A., Gossel, W. and Peter, W., (2015) "Groundwater Management Options in arid environment: The Nubian Sandstone Aquifer System, Eastern Sahara”, Journal of Arid Environments, 122 (1), 46-58.

Thorweihe, U., (1990) “Nubian Aquifer System”, in R. Said (ed.), the Geology of Egypt, Rotterdam, 601. Thorweihe, U. and Heinl, M., (1998) "Groundwater Resources of the Nubian Aquifer System", Paris, Berlin. UN. (1987) "Report of the World Commission on Environment and Development, Our common future".

Zhou, Y., Wang, L., Liu, J, Li, W., and Zheng, Y., (2012) "Options of Sustainable Groundwater Development in Beijing Plain, China", Physics and Chemistry of the Earth, 47, 99-113. 